\title{
The role of sardine as prey for pelagic predators in the western Mediterranean Sea assessed using stable isotopes and fatty acids
}

\author{
Luis Cardona $^{1, *}$, Laura Martínez-Iñigo ${ }^{1}$, Rafael Mateo ${ }^{2}$ Jacob González-Solís ${ }^{1}$ \\ ${ }^{1}$ Biodiversity Research Institute (IRBio) and Department of Animal Biology, Faculty of Biology, Universitat de Barcelona, \\ Av. Diagonal 643, 08028 Barcelona, Spain \\ ${ }^{2}$ Instituto de Investigación en Recursos Cinegéticos (IREC), CSIC-UCLM-JCCM, Ronda de Toledo s/n, 13071 Ciudad Real, Spain
}

ABSTRACT: This study combined the analysis of fatty acids and stable isotopes of nitrogen and carbon to test the hypothesis that the pelagic food web of the south Catalan Sea has a wasp-waist structure supported by sardines Sardina pilchardus. If this hypothesis were correct, most predators would be expected to have stable isotope ratios and fatty acid profiles consistent with those derived from a sardine-based diet. However, this was true only for mackerel Scomber scomber, blue butterfish Stromateus fiatola, all seabirds and oceanic loggerhead turtles Caretta caretta. The values of the DHA/EPA index of neritic loggerhead turtles and striped dolphins Stenella caeruleoalba were also consistent with a sardine/squid diet, but their trophic positions were too high. On the other hand, the DHA/EPA index of most predatory fishes indicated that anchovies Engraulis encrasicolus and/or horse mackerel Trachurus trachurus were their main prey. Nevertheless, some amounts of low trophic level invertebrates were likely to be consumed by some predatory fishes, because their trophic positions where lower than expected from a fish-based diet only. The heterogeneous distribution of phytoplankton groups above and below the thermocline during the warm season is hypothesized to be the primary reason for this food web structure, although the strong reliance of some seabirds on sardines is the likely consequence of a massive consumption of discards from fishing boats. In short, there is little evidence for a wasp-waist structure based on sardine, which may explain why the populations of predators fluctuate less than the population of sardines.

KEY WORDS: Anchovy · Engraulis encrasicolus · Fatty acids · Food web · Sardina pilchardus · Sardine · Stable isotope $\cdot$ Top predator
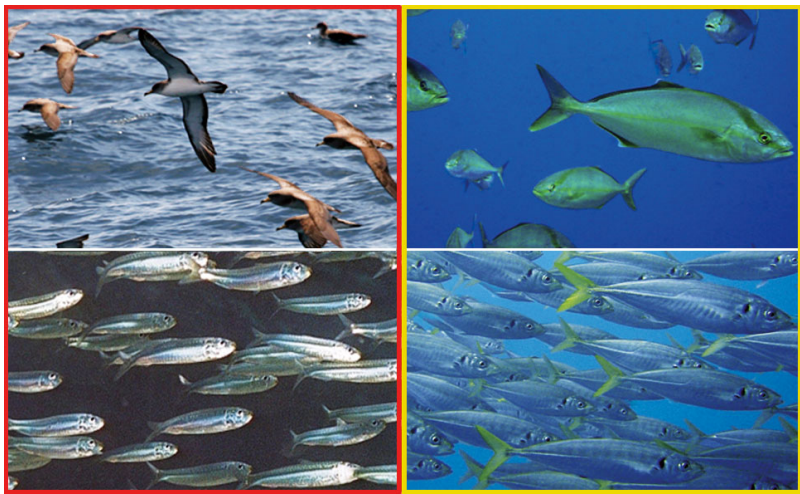

In summer, 2 parallel pelagic food webs coexist in the Mediterranean Sea. Sardine is the main prey of most seabirds, whereas anchovy and horse mackerel support most of the predatory fishes.

Photos: Seabirds by Pep Arcos (SEO/BirdLife), sardines by Manuel Elices, amberjacks by Manuel Gazo, horse mackerel by Alex Llorente

\section{INTRODUCTION}

Marine food webs can be classified into 3 major groups according to the mechanisms controlling species abundance. In bottom-up systems, where the abundance of species at contiguous trophic levels is positively correlated, density-dependent mortality is caused by food limitation, which ultimately determines species abundance (Power 1992, Ware \& Thomson 2005). Conversely, in top-down systems, which are characterized by an inverse correlation in the biomass of species at contiguous trophic levels, the major determinant of species abundance is the 
density-independent mortality induced by predators (Power 1992, Paine 2010). Finally, wasp-waist ecosystems are characterized by the capacity of small, short-lived fishes occupying intermediate trophic levels to simultaneously control the abundance of zooplankton through predation as well as that of top predators through resource availability (Brodeur \& Pearcy 1992, Cury et al. 2000). Deciphering the control mode of each ecosystem is essential to predict the impact of fisheries, as these have not only reduced the abundance of top predators (Christensen et al. 2003), but also eroded the abundance of species at intermediate trophic levels (Palomera et al. 2007). This is particularly important in wasp-waist ecosystems, where the whole food web is highly sensitive to the overfishing of small pelagic fishes (Cury et al. 2000, Shannon et al. 2000, Bakun 2006).

Although wasp-waist ecosystems are usually associated to the world's eastern boundary currents that undergo seasonal upwelling (Cury et al. 2000), they also exist in other regions with large populations of small pelagic fishes (Bakun 2006). In the Mediterranean Sea, European sardines Sardina pilchardus and European anchovies Engraulis encrasicolus occupy slightly different ecological niches but both abound in the most productive regions of the basin, which are fertilized either by upwelling or freshwater runoff (Palomera et al. 2007, Costalago et al. 2012). Ecosystem modeling has suggested a possible wasp-waist structure for those ecosystems, with a key role for sardines in the south Catalan Sea (Coll et al. 2006, Palomera et al. 2007, Coll et al. 2008).

Recent research using stable isotope analysis has revealed that some top predators inhabiting waspwaist ecosystems consume more crustaceans and gelatinous zooplankton than previously thought (Cardona et al. 2012, Madigan et al. 2012). This suggests a more complex food web structure, since predators would feed on multiple trophic levels in parallel food webs (Olsen et al. 2001, Darnaude et al. 2004, Frisch et al. 2014), with important implications on ecosystem stability and resilience (Gross et al. 2009). However, the small variability of $\delta^{13} \mathrm{C}$ values at the base of pelagic food webs (Cardona et al. 2012, Madigan et al. 2012, Stowasser et al. 2012) impairs the discriminating power of the isotopic mixing models used to reconstruct the diet of predators, because of high uncertainty about the feasible contribution of potential prey to the diet of predators (Cardona et al. 2012, Madigan et al. 2012).

Fatty acids offer an alternative set of intrinsic markers that can help us improve the resolution of food web structure. Phytoplankton, microzooplankton and bacteria all produce taxon-specific fatty acids that are retained by their predators and can be used to identify the sources of fatty acids (Dalsgaard et al. 2003, Ramos \& González-Solís 2012). Fatty acids have even used for quantitative diet reconstruction, although the method is limited by the necessity of experimentally assessing the calibration coefficients (Iverson et al. 2004). Because fatty acids are more specific to dietary source compared to $\delta^{13} \mathrm{C}$, they can alleviate some of the ambiguities that result from using stable isotopes alone, particularly in cases where the differences between $\delta^{13} \mathrm{C}$ of different carbon sources are small (Nyssen et al. 2005, Alfaro et al. 2006, Perga et al. 2006, El-Sabaawi et al. 2009). Recently, Pethybridge et al. (2014) reported that differences in the fatty acid profiles of sardines and anchovies from the Gulf of Lions related to a differential exploitation of dinoflagellates and diatoms, thus suggesting that fatty acids may help to elucidate the relative importance of sardines and anchovies as forage for predators.

The main aim of this study was to combine the analysis of fatty acids and stable isotopes of nitrogen and carbon to test the hypothesis that the pelagic ecosystem in the south Catalan Sea (Mediterranean Sea) has a wasp-waist structure, where sardines would be the major prey of most predators (Coll et al. 2006, Palomera et al. 2007, Coll et al. 2008). If so, the fatty acid profiles of predators would be closer to those of sardines than to those of anchovies and other low trophic level species.

\section{MATERIALS AND METHODS}

\section{Sampling}

Sampling of most species was conducted in 2006, although that of seabirds extended until 2010 due to the opportunistic nature of sampling. Only samples collected from May to July were considered for analysis, to reduce as much as possible the effects of seasonal variations in the fatty acid profiles of small forage fishes (Bandarra et al. 2001, Zlatanos \& Laskaridis 2007, Celik 2008, Pethybridge et al. 2014) and crustaceans (Mayzaud et al. 1999). The fatty acid profiles and the stable isotope ratios of fish muscle integrate those of the diet consumed throughout the last 3 mo (Robin et al. 2003, Buchheister \& Latour 2010). Accordingly, stable isotope ratios and fatty acid profiles samples are expected to integrate those in the local forage species as long as predators remain within the area for at least 3 mo. 
Small pelagic fishes, squids and neritic predatory fishes (see Table 1) were sampled from the catches landed at the harbors of Vilanova i la Geltrú and Sant Carles de la Ràpita by commercial vessels operating in the south Catalan Sea (Fig. 1). Krill Meganyctiphanes norvegica were collected from the stomach contents of bullet tuna. Blue sharks and some large predatory fishes (see Table 1) were captured by commercial longliners operating in a nearby off-shore area (Fig. 1) and the tissue samples of these species were collected by observers on board. Pink jellyfish Pelagia noctiluca were collected with a dip net during the fishing operations. Oceanic loggerhead turtles Caretta caretta and seabirds were caught incidentally by fishermen operating in those areas and samples were collected by onboard observers. Samples from neritic loggerhead turtles and striped dolphin Stenella caeruleoalba were collected from dead stranded individuals (Fig. 1).

White dorsolateral muscle was sampled from all fishes, as well as mantle from the cephalopods and pectoral muscle from turtles, dolphins and seabirds. Jellyfish and krill were fully homogenized. Samples were stored at $-20^{\circ} \mathrm{C}$ prior to analysis. Samples for fatty acid analysis are usually stored at $-80^{\circ} \mathrm{C}$ to avoid degradation of unsaturated fatty acids (Guitart et al. 1999). However, this is impractical when considering large fishes, sea turtles, dolphins and seabirds, as they are often sampled opportunistically. Nevertheless, it has been shown that most of the ecologically relevant information is retained in the fatty acid profiles of fishes even when stored at temperatures higher than $-80^{\circ} \mathrm{C}$ (Chaijan et al. 2006).

\section{Stable isotope analysis}

Once thawed, tissues were dried for $24 \mathrm{~h}$ at $60^{\circ} \mathrm{C}$ and ground to a fine powder; lipids were then extracted with a chloroform/methanol (2:1) solution. Crustacean samples were split into 2 subsamples. One subsample was treated with $0.5 \mathrm{~N} \mathrm{HCl}$ to remove the inorganic carbonates of the skeleton and avoid any bias in the $\delta^{13} \mathrm{C}$. However, acidification may modify the relative concentration of
$\mathrm{N}$ isotopes, so the other subsample was used to determine the $\delta^{15} \mathrm{~N}$ value. All of the samples were weighed into tin cups, combusted at $1000^{\circ} \mathrm{C}$, and analyzed in a Flash 1112 IRMS Delta C Series EA Thermo Finnigan continuous flow isotope ratio mass spectrometer. Stable isotope abundances were expressed in $\delta$ notation according to the following expression:

$$
\delta X=\left[\left(R_{\text {sample }} / R_{\text {standard }}\right)-1\right] \times 1000
$$

where $X$ is ${ }^{13} \mathrm{C}$ or ${ }^{15} \mathrm{~N}$ and $R_{\text {sample }}$ and $R_{\text {standard }}$ is the corresponding ratio ${ }^{13} \mathrm{C} /{ }^{12} \mathrm{C}$ or ${ }^{15} \mathrm{~N} /{ }^{14} \mathrm{~N}$ of the sample and the standard. The standards for ${ }^{13} \mathrm{C}$ and ${ }^{15} \mathrm{~N}$ were Vienna Pee Dee Belemnite (VPDB) and atmospheric nitrogen (air), respectively. International isotope secondary standards for carbon (IAEA $\mathrm{CH}_{6}\left[\delta^{13} \mathrm{C}=\right.$ $-10.4 \%]$, USGS $24\left[\delta^{13} \mathrm{C}=-16.1 \%\right]$, IAEA $\mathrm{CH}_{7}\left[\delta^{13} \mathrm{C}\right.$ $=-31.8 \%$ o]) were used to a precision of $0.2 \%$, and for nitrogen (IAEA NO $\mathrm{NO}_{3}\left[\delta^{15} \mathrm{~N}=+4.7 \%\right.$ o], IAEA $\mathrm{N}_{2}\left[\delta^{15} \mathrm{~N}=\right.$ $+20.3 \%$, IAEA $\mathrm{N}_{1}\left[\delta^{15} \mathrm{~N}=+0.4 \%\right]$ ) to a precision of $0.3 \%$.

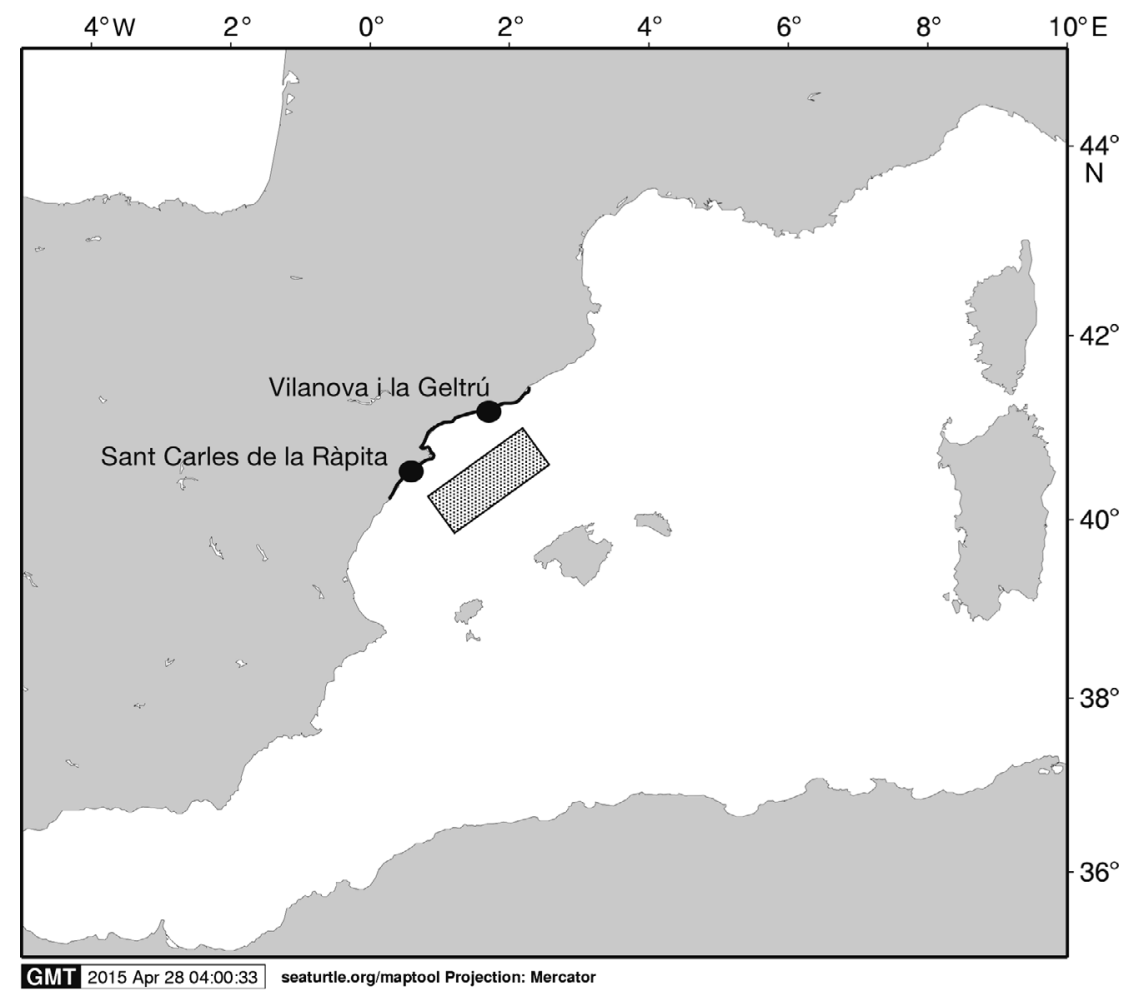

Fig. 1. Study region. Small pelagic fishes, squids and neritic predators were sampled from the catches landed at the harbors of Vilanova i la Geltrú and Sant Carles de la Ràpita. Dead stranded neritic loggerhead turtles Caretta caretta and striped dolphin Stenella caeruleoalba were collected along the stretch of coastline in bold. The rectangle denotes the area where longliners captured large predatory fishes and where pink jellyish Pelagia noctiluca were collected during fishing operations. Seabirds were captured incidentally over the entire region 


\section{Fatty acid analysis}

The fatty acid composition was determined after methylation following the method used by Mateo et al. (2003), but using mass spectrometry for the identification and quantification of the wide range of fatty acids present in these samples. Briefly, each sample $(0.3 \mathrm{~g})$ was homogenized in 9 parts of $\mathrm{Na}_{2} \mathrm{SO}_{4}(2.7 \mathrm{~g})$ before transferring it into $15 \mathrm{ml}$ Pyrex tubes with teflon caps, at which time $10 \mu \mathrm{l}$ of internal standard was added (13:0, tridecanoic acid, $10 \mu \mathrm{g} \mathrm{ml}^{-1}$ ). Then, we added $4 \mathrm{ml}$ of $\mathrm{H}_{2} \mathrm{SO}_{4} 1 \mathrm{~N}$ in methanol to each tube, after which they were topped with $\mathrm{N}_{2}$ and closed, heated in an oven $\left(80^{\circ} \mathrm{C}\right)$ for $6 \mathrm{~h}$, and shaken every hour. Subsequently, the methylation reaction continued for $12 \mathrm{~h}$ at $60^{\circ} \mathrm{C}$. Once cooled, fatty acid methylesters (FAMEs) were extracted with $1.7 \mathrm{ml}$ of hexane after adding $4 \mathrm{ml}$ of ultrapure water (Milli-Q) to each tube. For this, the tubes were horizontally shaken for $5 \mathrm{~min}$ and then centrifuged $(626 \times g)$ for another $5 \mathrm{~min}$. The upper phase of hexane containing the FAMEs was transferred into $2 \mathrm{ml}$ chromatographic vials, topped with $\mathrm{N}_{2}$ and analyzed by gas chromatography coupled to mass spectrometry (GCMS). The analysis was carried out using an Agilent Technologies 6890N GC Network System with a 7683 series injector and coupled to an electronic impact-mass spectrometry detector (EI-MS, 5973N MSD). The capillary column was a BPX70 column (SGE, $30 \mathrm{~m} \times, 0.25 \mathrm{~mm}$ i.d., $0.25 \mu \mathrm{m}$ film thickness). The injector in split mode (20:1) was set at a temperature of $270^{\circ} \mathrm{C}$ and the oven was maintained for $5 \mathrm{~min}$ at $100^{\circ} \mathrm{C}$ after injection and then increased to $240^{\circ} \mathrm{C}$ at a ramp rate of $2.5^{\circ} \mathrm{C} \mathrm{min}^{-1}$. The carrier gas was helium at a flow rate of $1.2 \mathrm{ml} \mathrm{min}^{-1}$. The source inlet of the mass spectrometer was held at $230^{\circ} \mathrm{C}$ and $70 \mathrm{~V}$. The identification and quantification were achieved by comparison to retention times of FAME reference standards (FAMQ-005, AccuStandard) and the mass spectra. Blanks were processed with each batch of samples. This method has been used before for the analysis of fatty acid composition in several marine species (Guitart et al. 1996, 1999, Mateo et al. 2004) and the previously obtained chromatographic information about fatty acids profiles was useful for the identification of the fatty acids in this study.

\section{Statistical analysis}

If potential prey do not differ in the average values of $\delta^{13} \mathrm{C}, \delta^{15} \mathrm{~N}$ and the DHA/EPA index, these biochemical markers would not be able to trace the food sources of predators. Accordingly, 1-way ANOVA, followed by Tukey post-hoc tests, was used to compare the average values of $\delta^{13} \mathrm{C}, \delta^{15} \mathrm{~N}$ and the DHA/EPA index of krill, pink jellyfish, longfin squid Loligo vulgaris, sardines, anchovies and horse mackerel Trachurus trachurus. Levene's test was used to check for homoscedasticity.

Only fatty acids that had an overall mean of $>0.4 \%$ of total fatty acids were considered for latter analysis (Iverson et al. 2002). Data were standardized prior to analysis to have zero mean and unit variance and principal component analysis (PCA) was used to explore the sources of variability with the fatty acid profiles of the assemblage. Most of the variability was associated with saturated or monosaturated fatty acids, unlikely to be conserved from predator to predator (Ramos \& González-Solís 2012), or rare saturated fatty acids of unknown ecological significance (see 'Results'). Accordingly, we focused on the 22:6n-3 to 20:5n-3 ratio (or DHA/ EPA index) for further analysis, as they were the 2 most abundant and variable polyunsaturated fatty acids in the samples and were expected to be conserved from prey to predator (Ramos \& GonzálezSolís 2012).

Potential consumers of sardines were identified, assuming that the value of the DHA/EPA does not change from prey to predator (Ramos \& GonzálezSolís 2012) and assuming the following trophic enrichment factors: $1.4 \%$ for $\delta^{15} \mathrm{~N}$ for seabird muscle (Hobson \& Clark 1992) and 2.6\% $\delta^{15} \mathrm{~N}$ for bony fish muscle (Pinnegar \& Polunin 1999). We are not aware of any published trophic enrichment factors experimentally derived for dolphin and sea turtle muscle.

All calculations were performed with IBM SPSS Statistics 20 .

\section{RESULTS}

\section{Stable isotopes}

Only krill differed in average $\delta^{13} \mathrm{C}$ from other potential prey (ANOVA: $F_{5,29}=28.090, \mathrm{p}<0.001 ; \mathrm{n}=5$ each species, Tukey as post-hoc test; Fig. 2). Variability between forage species was larger for the $\delta^{15} \mathrm{~N}$ values, as krill and pink jellyfish were significantly depleted in ${ }^{15} \mathrm{~N}$ when compared with the other species. The average $\delta^{15} \mathrm{~N}$ value of horse mackerel was significantly higher than that of sardines but not different from those of anchovies and longfin squids (ANOVA: $F_{5,29}=68.035, \mathrm{p}<0.001 ; \mathrm{n}=5$ each species, Tukey as post-hoc test; Fig. 2). 

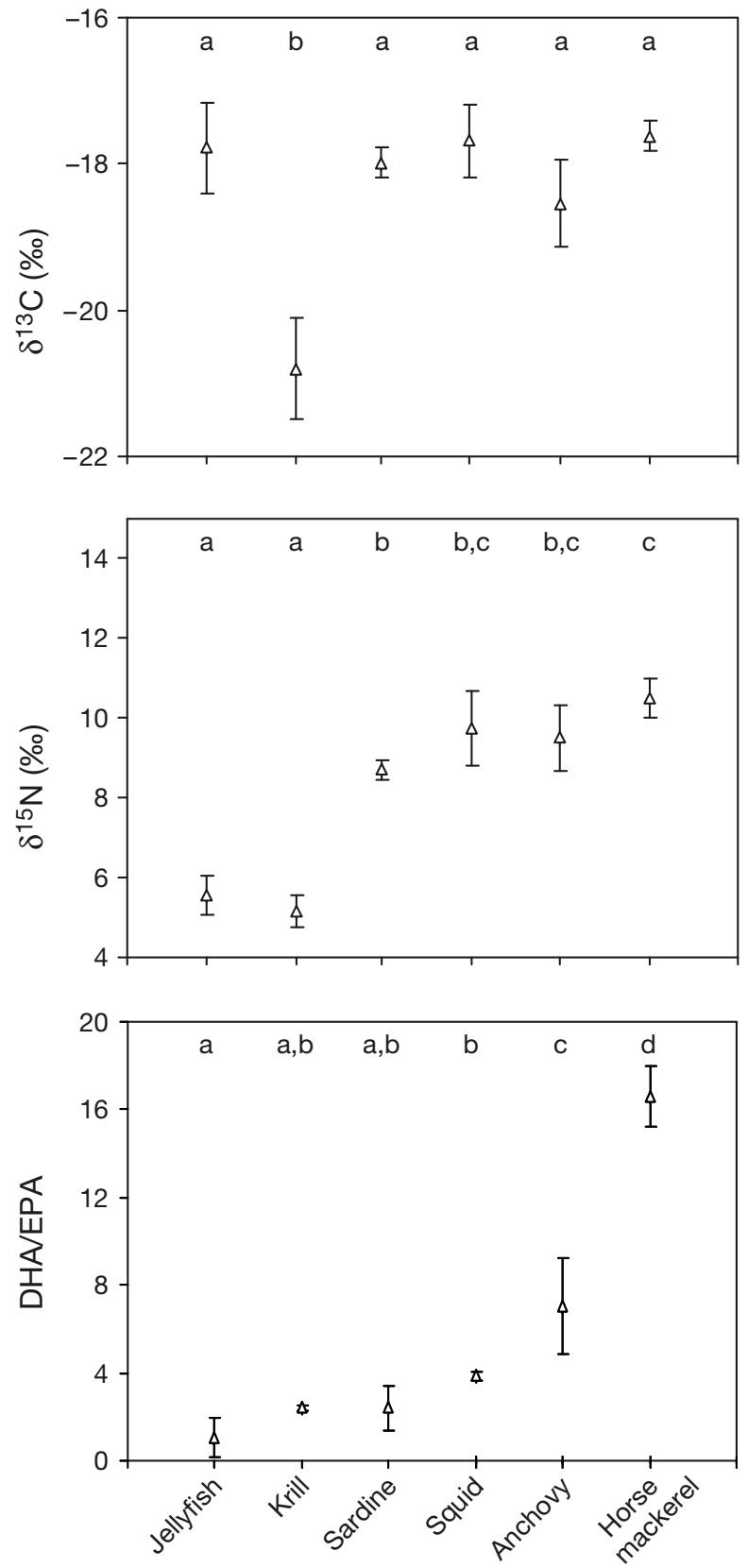

Fig. 2. Biochemical markers of potential prey. Species sharing superscript letters within the same panel are not significantly different based on Tukey's post-hoc test

Most predatory fishes overlapped within a narrow range of $\delta^{13} \mathrm{C}$ values, but scatter was larger for airbreathing predators, with seabirds usually more enriched in ${ }^{13} \mathrm{C}$ than fishes and sea turtles, and dolphins overlapping with fishes (Fig. 3). Considering the average $\delta^{13} \mathrm{C}$ of krill $(-20.8 \pm 0.7 \%)$, that of the remaining potential prey $(-17.9 \pm 0.6 \%)$ and the trophic discrimination factors reported for seabirds and fishes (see 'Materials and methods'), krill was the most likely low trophic level prey consumed by Balearic and Mediterranean shearwaters, bullet tuna and mackerel.

Scatter of predators along the $\delta^{15} \mathrm{~N}$ axis was larger than along the $\delta^{13} \mathrm{C}$ axis, although most predatory fishes overlapped within a narrow range (Fig. 3). The average $\delta^{15} \mathrm{~N}$ value of most predators was consistent with a sardine/squid-based diet (Fig. 3), according to the trophic discrimination factors reported for seabirds and fishes (see 'Materials and Methods'). Only blue shark, bluefish and leerfish had a trophic level higher than expected and bullet tuna and dolphinfish a lower one. However, the fatty acid profiles of most predators indicated that they relied on other forage species and not sardines (see below).

\section{Fatty acids}

The fatty acid profiles of all the potential prey species were dominated by 16:0, 18:0, 20:5n-3 and 22:6n-3 (Table 1; Table S1 in the Supplement at www.int-res.com/articles/suppl/m531p001_supp.xls), but major differences existed between species. Pink jellyfish differed from all other species because of their very high levels of 16:0 and very low levels of 22:6n-3, whereas krill, longfin squid and sardines were more enriched in 20:5n-3 than anchovies and horse mackerel. Accordingly, the highest average DHA/EPA index was that of horse mackerel, followed by that of anchovies and finally those of the other 4 potential prey species (ANOVA $F_{5,29}=99.686$, $\mathrm{p}<0.001$, Tukey as post-hoc test; Fig. 2). The fatty acid profiles of predatory fishes, seabirds, sea turtles and striped dolphins were also dominated by 16:0, $18: 0,20: 5 n-3$ and 22:6n-3, but levels of 18:0 were usually much higher than those in potential prey species (Table 1). Furthermore, loggerhead turtle, striped dolphin and seabirds differed from invertebrates and fishes in their low levels of 22:6n-3 and high levels of 18:2n-6 and 20:4n-6 (Table S1).

PCA extracted as many as 8 components with an eigenvalue $>1$ to explain $76.6 \%$ of the overall variability in the fatty acid profiles of the 32 groups considered (31 species and 2 groups of loggerhead turtles). According to the loadings of the 3 first components, most of that variability was associated with $14: 0,15: 0,16: 0,16: 1-n 13,18: 00,18: 3 n-3,20: 2 n-7$, 20:4n-6, 20:5n-3 and 22:6n-3 (Table 2). The first component (PC1) explained $28.4 \%$ of the overall variability in the fatty acid profiles and opposed the abundance of 16:0 and 22:6n-3 to that of all the other fatty acids. The high loading for $20: 2 n-7$ is remarkable 

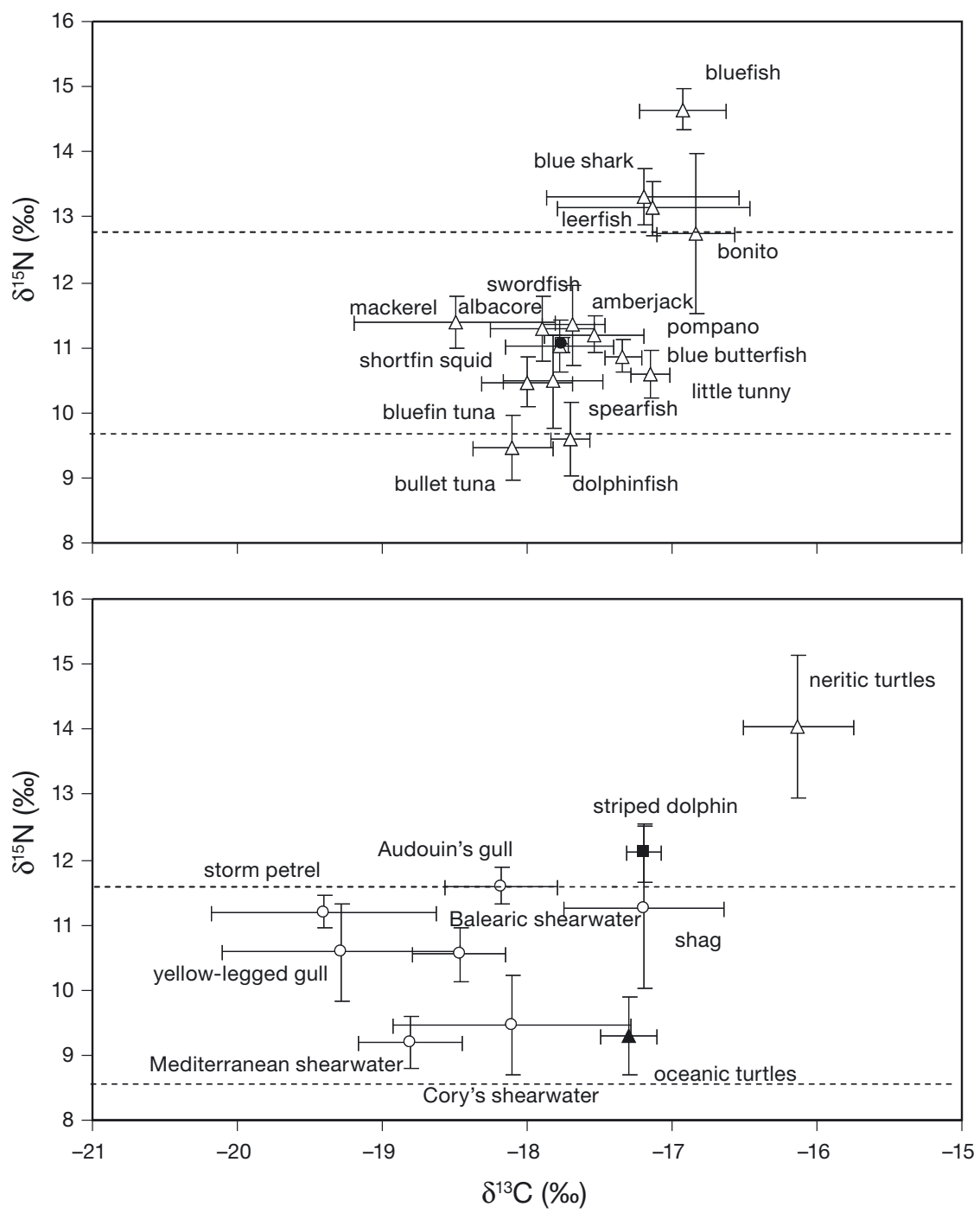

Fig. 3. Scatterplot of sharks, fishes and large squids (top panel) and air-breathing predators (bottom panel) into the $\delta^{13} \mathrm{C}-\delta^{15} \mathrm{~N}$ space. Arithmetic mean and standard deviation are shown for each species. Dashed lines show the expected higher and lower threshold of $\delta^{15} \mathrm{~N}$ for predators with an exclusive sardine/squid-based diet, according to the trophic discrimination factors expected for each group. Open triangles denote sharks and fishes, open circles seabirds, filled triangles turtles, filled circles large squid and filled squares dolphins

(Table 2), as this fatty acid was scarce in most samples except in sardines and mackerel (Table S1). The second component (PC2) explained $13.0 \%$ of the overall variability in the fatty acid profiles and was strongly influenced by the abundance of $18: 0$ and 20:4n-6 (positive values) as well as 14:0 and 22:6n-3 (negative values).The third component (PC3) explained $10.3 \%$ of the overall variability in the fatty acid profiles and was strongly influenced by the abundance of 16:0 and 16:1-n13 (positive values) as well as 18:3n-3 and 20:5n-3 (negative values).
When plotted into the PC1-PC2 space, potential prey species were widely scattered over the PC1 axis and predators were scattered along both the PC1 and PC2 axis (Fig. 4). This suggests that fatty acids offered better discrimination between food sources than $\delta^{13} \mathrm{C}$ did. However, most of the variability was associated with saturated fatty acids (14:0, 16:0 and $18: 0$ ) or monosaturated fatty acids (16:1-n13), unlikely to be conserved from predator to predator. Furthermore, the dietary significance of 20:2n-7 and 20:4n-6 was unclear. Accordingly, we focused on the relative abundance of the other major polyunsaturated fatty acids (22:6n-3 and 20:5n-3) and used the DHA/EPA index for further analysis, as its dietary significance is well known. Jellyfish, krill, sardines and squid were characterized by low values of the DHA/EPA index, anchovies had an intermediate value and horse mackerel was the species with the highest value (ANOVA $F_{5,29}=$ 99.686, $\mathrm{p}<0.001$, Tukey as post-hoc test; Fig. 2).

\section{Potential sardine consumers}

As sardines and longfin squids did not differ in their average DHA/EPA index and $\delta^{15} \mathrm{~N}$ values (Fig. 2), we pooled them to set up the expected range of values of potential sardine consumers. The values of their DHA/ EPA indices ranged from 1.5 to 4.2 and those of $\delta^{15} \mathrm{~N}$ from 7.75 to 10.23 (Table S1 in the Supplement). Accordingly, only predators with values of the DHA/ EPA index lower than 4.15 and $\delta^{15} \mathrm{~N}$ values ranging from 9.85 to 12.83 (fishes) or from 8.65 to 11.65 (seabirds) were likely to have diets based exclusively on sardines/squid. Only mackerel, blue butterfish and all the seabirds fit both requisites (Fig. 5). Neritic loggerhead turtles and striped dolphins may also consume large amounts of sardines and squids, according to the DHA/EPA index, but they are at a trophic level higher than expected for a diet based solely on sardines and squid (Fig. 5). 


\section{DISCUSSION}

The results reported here do not support the existence of a sardine-based wasp-waist ecosystem in the south Catalan Sea. Instead, fatty acid profiles revealed that only a handful of predators may rely primarily on sardines and/or longfin squids (Fig. 6). Discriminating between these 2 prey species is not possible, because they did not differ in the average values of the biochemical markers used here. Mackerel, blue butterfish, all the seabirds, sea turtles and striped dolphins where characterized by high levels of 20:5n-3 and low levels of 22:6n-3, consistent with a sardine/squid-based diet. Nevertheless, the trophic position of striped dolphins and neritic loggerhead turtles was too high to rely only on sardines and/or longfin squids as their major diet.

A second group of predators included blue shark and most predatory fishes and was characterized by high levels of 22:6n-3 and low levels of 20:5n-3. This suggests an anchovy/horse mackerel-based diet, although the consumption of some low trophic level invertebrates enriched in 22:6n-3, such as jellyfish and krill, cannot be ruled out on the basis of the $\delta^{15} \mathrm{~N}$ values of most predators. On the other hand, the trophic positon of bluefish, leerfish and blue shark was too high to be consistent with an exclusive anchovy/horse mackerel diet. Furthermore, the values of the DHA/EPA index of amberjack and blue shark were much higher than those of any potential

Table 1. Body size and relative abundance (mean \pm SD) of the 4 major fatty acids in the species considered. Length comprises total length for fishes and dolphins, mantle length for squids and curved carapace length for sea turtles

\begin{tabular}{|c|c|c|c|c|c|c|c|}
\hline \multirow{2}{*}{$\overline{\text { Scientific name }}$ Species } & \multirow[b]{2}{*}{ Common name } & \multirow[t]{2}{*}{$\mathrm{n}$} & \multirow{2}{*}{$\begin{array}{l}\text { Length } \\
\text { (cm) }\end{array}$} & \multicolumn{4}{|c|}{ Relative abundance of major fatty acids ( $\%$} \\
\hline & & & & $16: 00$ & $18: 00$ & $20: 5 n-3$ & $22: 6 n-3$ \\
\hline \multicolumn{8}{|l|}{ Potential prey } \\
\hline Engraulis encrasicolus & Anchovy & 5 & $11-14$ & $28 \pm 4$ & $5 \pm 1$ & $7 \pm 1$ & $46 \pm 7$ \\
\hline Loligo vulgaris & Longfin squid & 5 & $9-11$ & $26 \pm 1$ & $4 \pm 1$ & $12 \pm 1$ & $47 \pm 1$ \\
\hline Meganyctiphanes norvegica & Krill & 5 & - & $21 \pm 1$ & $2 \pm 1$ & $19 \pm 1$ & $39 \pm 1$ \\
\hline Pelagia noctiluca & Pink jellyfish & 5 & - & $69 \pm 20$ & $15 \pm 10$ & $6 \pm 6$ & $2 \pm 1$ \\
\hline Sardina pilchardus & Sardine & 5 & $13-17$ & $23 \pm 3$ & $5 \pm 1$ & $9 \pm 3$ & $24 \pm 9$ \\
\hline Trachurus trachurus & Horse mackerel & 5 & $15-22$ & $20 \pm 3$ & $8 \pm 1$ & $4 \pm 1$ & $60 \pm 2$ \\
\hline \multicolumn{8}{|l|}{ Mesopredators } \\
\hline Auxis rochei & Bullet tuna & 5 & $35-45$ & $29 \pm 7$ & $10 \pm 2$ & $6 \pm 1$ & $37 \pm 12$ \\
\hline Sarda sarda & Bonito & 6 & $43-60$ & $30 \pm 8$ & $13 \pm 3$ & $5 \pm 4$ & $28 \pm 15$ \\
\hline Scomber scombrus & Mackerel & 5 & $24-28$ & $24 \pm 2$ & $7 \pm 2$ & $8 \pm 1$ & $26 \pm 4$ \\
\hline Seriola dumerili & Amberjack & 5 & $25-27$ & $18 \pm 4$ & $13 \pm 2$ & $2 \pm 1$ & $46 \pm 8$ \\
\hline Stromateus fiatola & Blue butterfish & 5 & $41-55$ & $35 \pm 3$ & $15 \pm 1$ & $3 \pm 1$ & $10 \pm 2$ \\
\hline Todarodes sagittatus & Shortfin squid & 5 & $25-36$ & $23 \pm 2$ & $4 \pm 1$ & $11 \pm 1$ & $56 \pm 4$ \\
\hline Trachinotus ovatus & Pompano & 6 & $33-38$ & $29 \pm 7$ & $11 \pm 2$ & $3 \pm 1$ & $29 \pm 15$ \\
\hline \multicolumn{8}{|l|}{ Large predatory fishes } \\
\hline Coryphaena hippurus & Dolphinfish & 4 & $47-99$ & $33 \pm 9$ & $18 \pm 5$ & $2 \pm 1$ & $29 \pm 16$ \\
\hline Euthynnus alletteratus & Little tunny & 4 & $65-80$ & $31 \pm 4$ & $15 \pm 3$ & $3 \pm 1$ & $33 \pm 11$ \\
\hline Lichia amia & Leerfish & 3 & $59-60$ & $24 \pm 1$ & $15 \pm 2$ & $3 \pm 1$ & $40 \pm 4$ \\
\hline Pomatomus saltatrix & Bluefish & 4 & $77-95$ & $26 \pm 1$ & $10 \pm 1$ & $3 \pm 1$ & $48 \pm 4$ \\
\hline Tetrapturus belone & Spearfish & 5 & $122-142$ & $22 \pm 3$ & $14 \pm 4$ & $3 \pm 1$ & $47 \pm 7$ \\
\hline Thunnus alalunga & Albacore & 5 & $77-92$ & $28 \pm 9$ & $11 \pm 2$ & $3 \pm 1$ & $36 \pm 22$ \\
\hline Thunnus thynnus & Bluefin tuna & 6 & $91-94$ & $26 \pm 7$ & $14 \pm 4$ & $3 \pm 1$ & $36 \pm 13$ \\
\hline Xiphias gladius & Swordfish & 5 & $120-168$ & $26 \pm 1$ & $11 \pm 5$ & $2 \pm 2$ & $20 \pm 9$ \\
\hline \multicolumn{8}{|l|}{ Sharks } \\
\hline Prionace glauca & Blue shark & 5 & $200-250$ & $25 \pm 2$ & $16 \pm 3$ & $1 \pm 1$ & $34 \pm 3$ \\
\hline \multicolumn{8}{|l|}{ Seabirds } \\
\hline Calonectris diomedea & Cory's shearwater & 10 & - & $21 \pm 2$ & $15 \pm 2$ & $7 \pm 1$ & $14 \pm 3$ \\
\hline Hydrobates pelagicus & Storm petrel & 3 & - & $23 \pm 1$ & $20 \pm 2$ & $5 \pm 1$ & $10 \pm 4$ \\
\hline Larus audouinii & Audouin's gull & 10 & - & $16 \pm 4$ & $18 \pm 2$ & $6 \pm 2$ & $12 \pm 2$ \\
\hline Larus michahellis & Yellow-legged gull & 11 & - & $22 \pm 4$ & $19 \pm 3$ & $4 \pm 3$ & $7 \pm 3$ \\
\hline Phalacrocorax aristotelis & Shag & 3 & - & $16 \pm 1$ & $23 \pm 2$ & $6 \pm 2$ & $6 \pm 1$ \\
\hline Puffinus mauretanicus & Balearic shearwater & 10 & - & $16 \pm 4$ & $22 \pm 2$ & $8 \pm 2$ & $16 \pm 3$ \\
\hline Puffinus yelkouan & Mediterranean shearwater & 10 & - & $16 \pm 3$ & $19 \pm 2$ & $9 \pm 2$ & $18 \pm 2$ \\
\hline \multicolumn{8}{|l|}{ Marine turtles } \\
\hline Caretta caretta & Loggerhead turtles (neritic) & 4 & $43-55$ & $14 \pm 5$ & $24 \pm 5$ & $6 \pm 2$ & $5 \pm 2$ \\
\hline Caretta caretta & Loggerhead turtles (oceanic) & 5 & $45-57$ & $27 \pm 5$ & $21 \pm 3$ & $4 \pm 1$ & $4 \pm 2$ \\
\hline \multicolumn{8}{|l|}{ Marine mammals } \\
\hline Stenella caeruleoalba & Striped dolphin & 5 & $180-220$ & $19 \pm 4$ & $21 \pm 6$ & $9 \pm 3$ & $10 \pm 3$ \\
\hline
\end{tabular}


Table 2. Component matrix for the 3 first principal components (PCs), which shows the correlation coefficients between the 34 fatty acids selected for analysis and the PCs. The 2 highest (positive) and lowest (negative) PCA scores for each axis are highlighted in bold

\begin{tabular}{|c|c|c|c|}
\hline Fatty Acid & PC1 & $\mathrm{PC} 2$ & PC3 \\
\hline 14:0 & 0.622 & -0.468 & -0.112 \\
\hline $15: 0$ & 0.683 & -0.456 & 0.145 \\
\hline $16: 0$ & -0.166 & -0.291 & 0.476 \\
\hline $17: 0$ & 0.476 & -0.124 & 0.286 \\
\hline $18: 0$ & 0.123 & 0.837 & -0.028 \\
\hline $20: 0$ & 0.869 & 0.127 & 0.040 \\
\hline $23: 0$ & 0.687 & 0.257 & 0.075 \\
\hline M16:0 anteiso & 0.735 & 0.015 & 0.136 \\
\hline M16:0 iso & 0.773 & -0.160 & 0.360 \\
\hline $16: 1 n-7$ & 0.772 & -0.237 & 0.327 \\
\hline $16: 1 n-9$ & 0.610 & 0.199 & -0.260 \\
\hline $16: 1 n-11$ & 0.383 & 0.190 & 0.052 \\
\hline $16: 1 n-13$ & 0.458 & -0.138 & 0.654 \\
\hline $17: 1 n-7$ & 0.732 & 0.224 & 0.237 \\
\hline $18: 1 n-7$ & 0.290 & 0.502 & -0.045 \\
\hline $18: 1 n-9$ & 0.545 & 0.547 & 0.101 \\
\hline $18: 1 n-13$ & 0.058 & 0.004 & 0.412 \\
\hline $20: 1 n-7$ & 0.266 & 0.059 & 0.038 \\
\hline $20: 1 n-9$ & 0.721 & -0.274 & -0.084 \\
\hline 20:1n-11 & 0.564 & 0.007 & -0.455 \\
\hline $22: 1 n-7$ & 0.524 & -0.371 & 0.234 \\
\hline $22: 1 n-9$ & 0.597 & -0.333 & -0.420 \\
\hline $24: 1 n-9$ & 0.221 & -0.145 & 0.480 \\
\hline $16: 3 n-3$ & 0.494 & -0.441 & -0.355 \\
\hline $18: 2 n-6$ & 0.414 & 0.519 & -0.382 \\
\hline $18: 3 n-3$ & 0.625 & 0.017 & -0.551 \\
\hline $18: 4 n-3$ & 0.530 & -0.529 & -0.294 \\
\hline $20: 2 n-7$ & 0.806 & 0.089 & -0.230 \\
\hline $20: 4 n-6$ & 0.204 & 0.807 & -0.159 \\
\hline $20: 5 n-3$ & 0.142 & -0.280 & -0.520 \\
\hline $22: 4 n-6$ & 0.233 & 0.429 & 0.467 \\
\hline $22: 5 n-3$ & 0.280 & 0.011 & -0.003 \\
\hline $22: 5 n-6$ & 0.230 & 0.109 & 0.528 \\
\hline $22: 6 n-3$ & -0.593 & -0.551 & 0.001 \\
\hline
\end{tabular}

prey considered here. The fatty acid profiles of some fishes are know to vary regionally within the western Mediterranean (Roncarati et al. 2012) and hence the high DHA/EPA values reported for amberjack and blue shark may reveal the use of foraging grounds beyond the limits of the study region. The standard deviation of the DHA/EPA of other predatory fishes was also large, although variability remained within the range of potential prey, which highlights the necessity for a large sample size to better characterize most species.

Despite those shortcomings, the results reported here clearly show that, at least in summer, sardines and longfin squids are minor prey for most of the predators studied. This interpretation is supported by available dietary information from elsewhere in the western Mediterranean, which reveals that sardines are seldom a major prey item of predatory fishes (Massutí et al. 1998, Sinopoli et al. 2004, Falautano et al. 2007, Mostarda et al. 2007, Castriota et al. 2008, Consoli et al. 2008, Romeo et al. 2009). This is in contrast with the high biomass of sardines in study region, where it is the most abundant small pelagic fish and dominates both fishery landings and discards (Coll et al. 2006).

It has to be noted, however, that the biomass of anchovies in the south Catalan Sea is only slightly lower than that of sardines (Coll et al. 2006) and other 22:6n-3 enriched species, such as juvenile horse mackerel, occur in high numbers over the shelf (Coll et al. 2006, 2008). Furthermore, during summer, sardines concentrate in pockets of low sea surface temperature and high chlorophyll over the upper continental shelf (Tugores et al. 2011, Saraux et al. 2014), which might limit its detection by most predators. On the contrary, anchovies are more scattered over the continental shelf, from coastal lagoons to the deepest parts of the shelf (Palomera et al. 2007, Cardona et al. 2008, Tugores et al. 2011, Giannoulaki et al. 2013, Saraux et al. 2014). Hence, during summer, anchovies and other 22:6n-3 enriched prey are probably more accessible than sardines (in terms of spatial homogeneity) for a large diversity of predators through the warm season, which may explain the results reported here.

The high reliance of seabirds on sardines during the warm season, indicated by their high levels of 20:5n-3 (this study) and stomach contents analysis (Oro et al. 1997, Ramos et al. 2009) may be related to their capacity to find the areas where sardines concentrate or boats are discarding trash fish. Many seabird species, such as Balearic shearwaters, Cory's shearwater, Audouin's gulls and yellow-legged gulls aggregate at trawlers (Oro et al. 1997, Arcos \& Oro 2002, Abelló et al. 2003, Ramos et al. 2009), whose discard is dominated by sardines (Coll et al. 2008). Schools of small pelagic fishes in the south Catalan Sea are usually found deeper than $25 \mathrm{~m}$ (Iglesias et al. 2003), but gulls do not dive at all and Cory's shearwaters dive much shallower than shearwaters in the genus Puffinus (Shealer 2001). This suggests that small pelagic fish are usually out of reach of gulls and Cory's shearwaters but within the reach of shearwaters in the genus Puffinus. Deeper diving might also explain why Balearic and Mediterranean shearwaters are more depleted in ${ }^{13} \mathrm{C}$ than Cory's shearwater, as deeper diving may increase accessibility to ${ }^{13} \mathrm{C}$-depleted krill. This difference in stable isotope ratios is unlikely to have a geographic basis, as at least Cory's and 

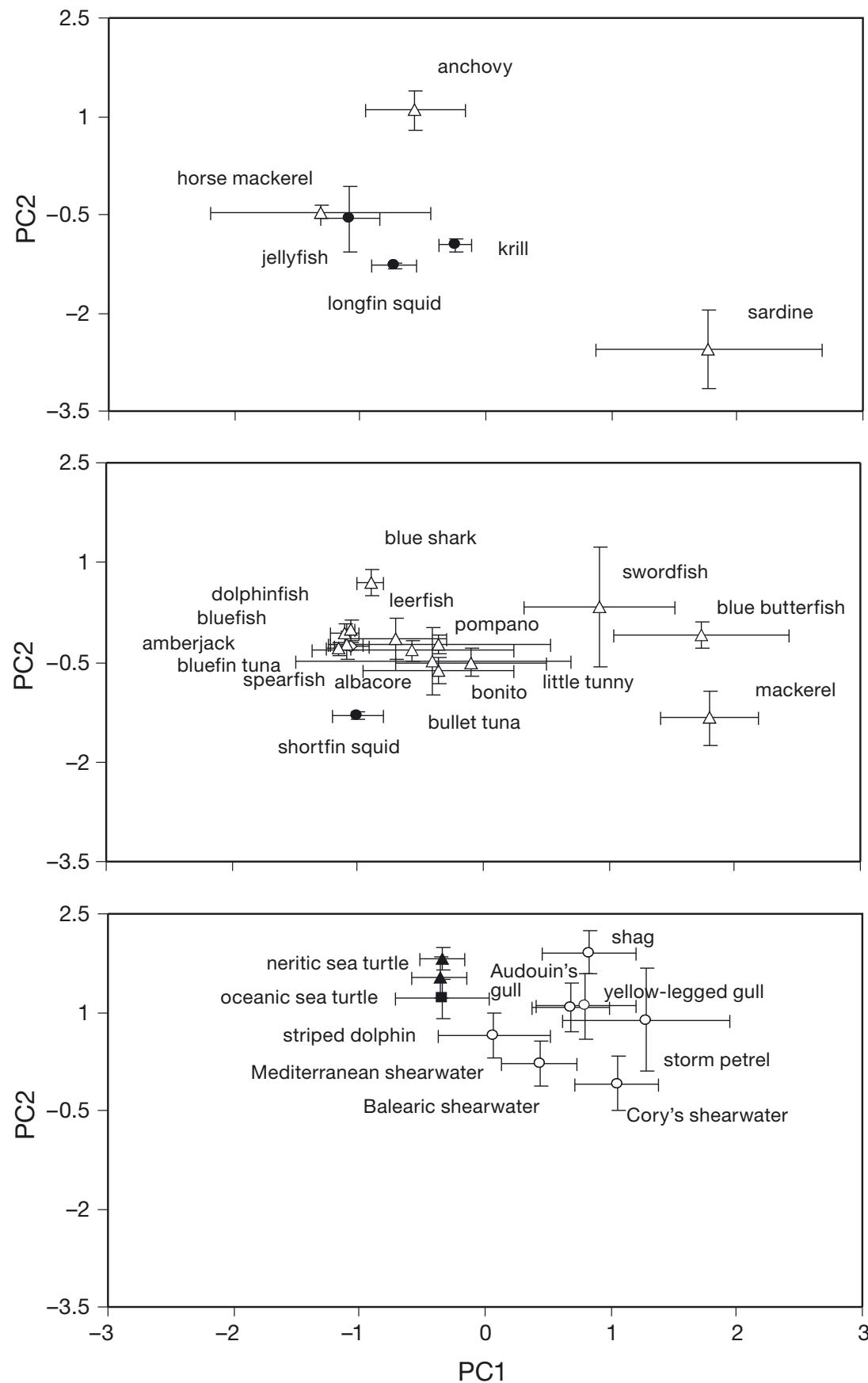

Fig. 4. Principal component analysis of potential prey (top panel), large squid, blue shark and fishes (central panel) and air-breathing predators (bottom panel) in the space defined by the first 2 principal components (PCs). Arithmetic mean and standard deviation are shown for each species. Open triangles denote sharks and fishes, open circles seabirds, filled triangles turtles, filled circles invertebrates and filled squares dolphins

Balearic shearwaters use the same foraging grounds in the south Catalan Sea (Arcos et al. 2009).

Although diet is the major determinant of fatty acid profiles (Sargent 1997, Shirai et al. 2002), physiology may also play a role. For instance, air-breathing mar- ine vertebrates usually accumulate $\mathrm{n}-6$ fatty acids (Guitart et al. 1996, this study), the level of 18:0 increases with trophic level (this study), and some fishes may synthesize some polyunsaturated fatty acids (Sargent 1997). However, the identification of 2 distinct groups of forage species and predators was based the DHA/EPA index and unlikely to be affected by the physiological factors reported above (Ramos \& González-Solís 2012). Importantly, turtles, seabirds and dolphins have DHA/EPA index values close to those of phylogenetically distant species such as krill, jellyfish and sardine-hence demonstrating that diet, and not physiology, was the main reason for the pattern reported here.

Seasonality is another potential confounding factor (Zlatanos \& Laskaridis, 2007, Pethybridge et al. 2014); hence, we considered only samples collected during the warm season. Fatty acid profiles and stable isotope ratios might also vary on an annual basis, but the standard deviation of the DHA/EPA index of seabirds was usually much lower than that of fishes, thus indicating that pooling samples from different yeas was not a major source of variability.

In summary, the evidence reported here does not support the existence of a wasp-waist ecosystem based on sardine, but a more complex scenario with 2 parallel food webs, one supported primarily by diatoms and the other by dinoflagellates and cyanobacteria. The existence of parallel food webs with limited exchange has already been reported in other marine ecosystems and is usually related to the existence of a microbial loop (Olsen et al. 2001) or limited benthic-pelagic coupling (Darnaude et al. 2004, Frisch et al. 2014). Here, we hypothesize that the existence of 2 parallel food webs might be related to the heterogeneous distributions of phytoplankton groups above and below the thermocline during the warm season.

Mediterranean phytoplankton is dominated by dinoflagellates and cyanobacteria during the thermal 

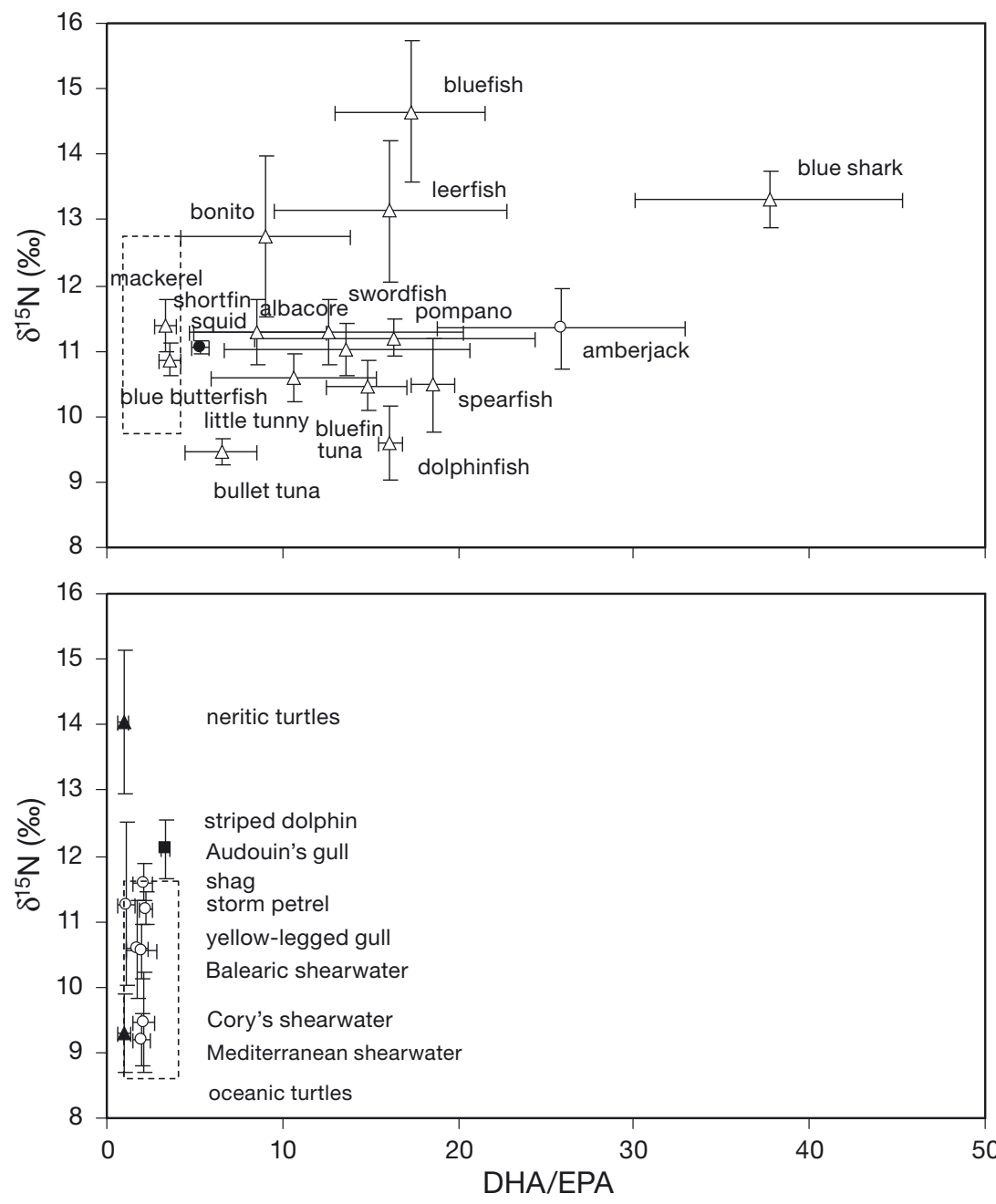

Fig. 5. Distribution of large squids, blue shark and fishes (top panel) and air-breathing predators (bottom panel) in the space defined by the DHA/EPA index and $\delta^{15} \mathrm{~N}$. Arithmetic mean and standard deviation are shown for each species. The dashed box shows the region of the graph where predators with a sardine/squid-based diet would be expected. Open triangles denote sharks and fishes, open circles seabirds, filled triangles turtles, filled circles invertebrates and filled squares dolphins

stratification period (Barlow et al. 1997, Charles et al. 2005), with diatoms present only below the thermocline (Marty et al. 2008). Dinoflagellates and cyanobacteria are depleted in 20:5n-3 and enriched in 22:6n-3 or 16:0 respectively, whereas the opposite is true for diatoms (Viso \& Marty 1993, Sargent 1997, Li et al. 1998, Patil et al. 2007). High levels of 22:6n-3 have already been reported for anchovies and horse mackerel elsewhere in the Mediterranean Sea (Bandarra et al. 2001, Zlatanos \& Laskaridis 2007, Fernandez-Jover et al. 2007, Celik 2008, Ozogul et al. 2008, Roncarati et al. 2012, Pethybridge et al. 2014) and likely reflect the prevalence of phytoplankton enriched in 22:6n-3 at the base of the summer food web. Although 20:5n-3 has a modest contribution to explaining the observed variability in the fatty acid profiles of most of the species studied here, the highest levels were observed in sardines, a feature also reported elsewhere in the Mediterranean Sea (Zlatanos \& Laskaridis 2007, Pethybridge et al. 2014). This suggests that diatoms are a more relevant source of fatty acids for sardines than for other species of small pelagic fishes in the region. This is confirmed by the high relevance of diatoms as prey for adult sardines during summer in the western Mediterranean revealed by dietary studies (Costalago et al. 2012).

Nevertheless, the existence of 2 parallel food webs may not persist year-round. Firstly, diatoms occur through the photic zone in winter (Marty et al. 2002, Charles et al. 2005), which results in an increase in the relative abundance of 20:5n-3 in anchovies and a fatty acid profile closer to that of sardines (Zlatanos \& Laskaridis 2007, Pethybridge et al. 2014). Secondly, sardines are more widespread over the continental shelf in winter (Tugores et al. 2011, Giannoulaki et al. 2013), which increases availability for a broader spectrum of predators. Furthermore, there is no evidence of coupling in the population dynamics of small pelagic fishes and their predators in the region. In a wasp-waist scenario, the populations of top predators are expected to fluctuate accordingly to changes in biomass of their prey (Cury et al. 2000). Sardines, anchovies and horse mackerel experience high fluctuations in biomass in the south Catalan Seas, linked to variability in winter mixing and freshwater runoff (Lloret et al. 2004, Coll et al. 2008), but there is little evidence for a coupling with predator biomass (Coll et al. 2008). This is probably because each species of small pelagic fish fluctuates independently (Lloret et al. 2004, Coll et al. 2008) and most predators probably shift prey according to availability, except those seabirds highly dependent on trawl discard (Navarro et al. 2009).

In conclusion, sardines are probably critical prey during the summer for seabirds, mackerel, blue butterfish and oceanic loggerhead turtles, but not for the remaining predators in the system, which rely primarily on anchovies and horse mackerel. The situation might be different in the cold season, when sardines are more widespread over the continental shelf. 
22:6n-3 enriched

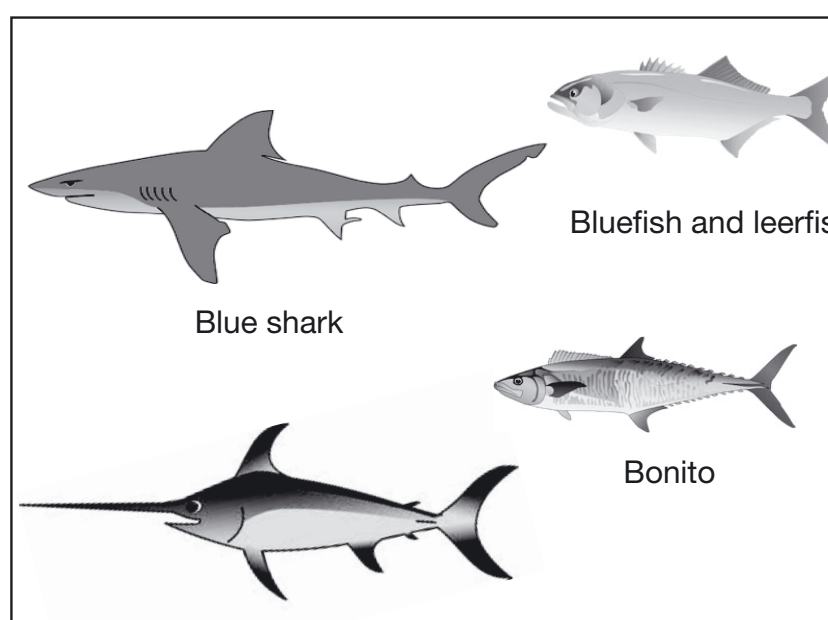

Swordfish and spearfish

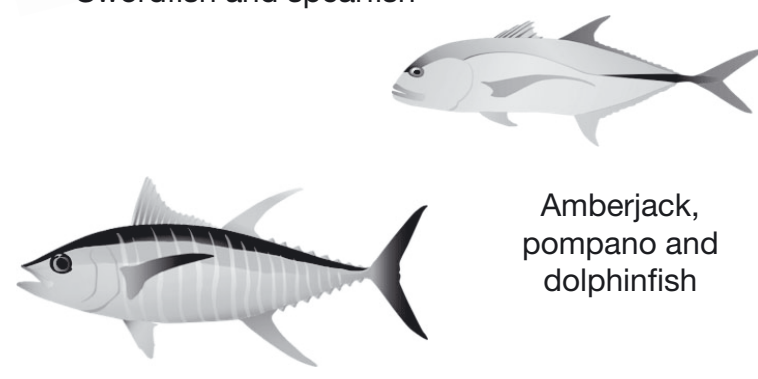

Albacore, bluefin tuna, little tunny and bullet tuna 20:5n-3 enriched

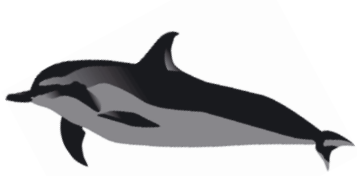

Striped dolphin

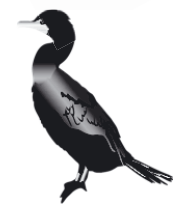

Shag

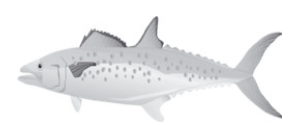

Mackerel and butterfish

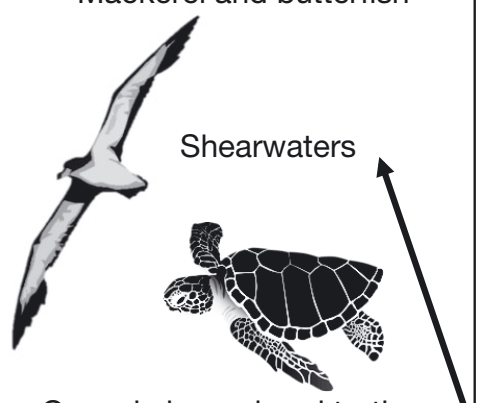

Oceanic loggerhead turtles
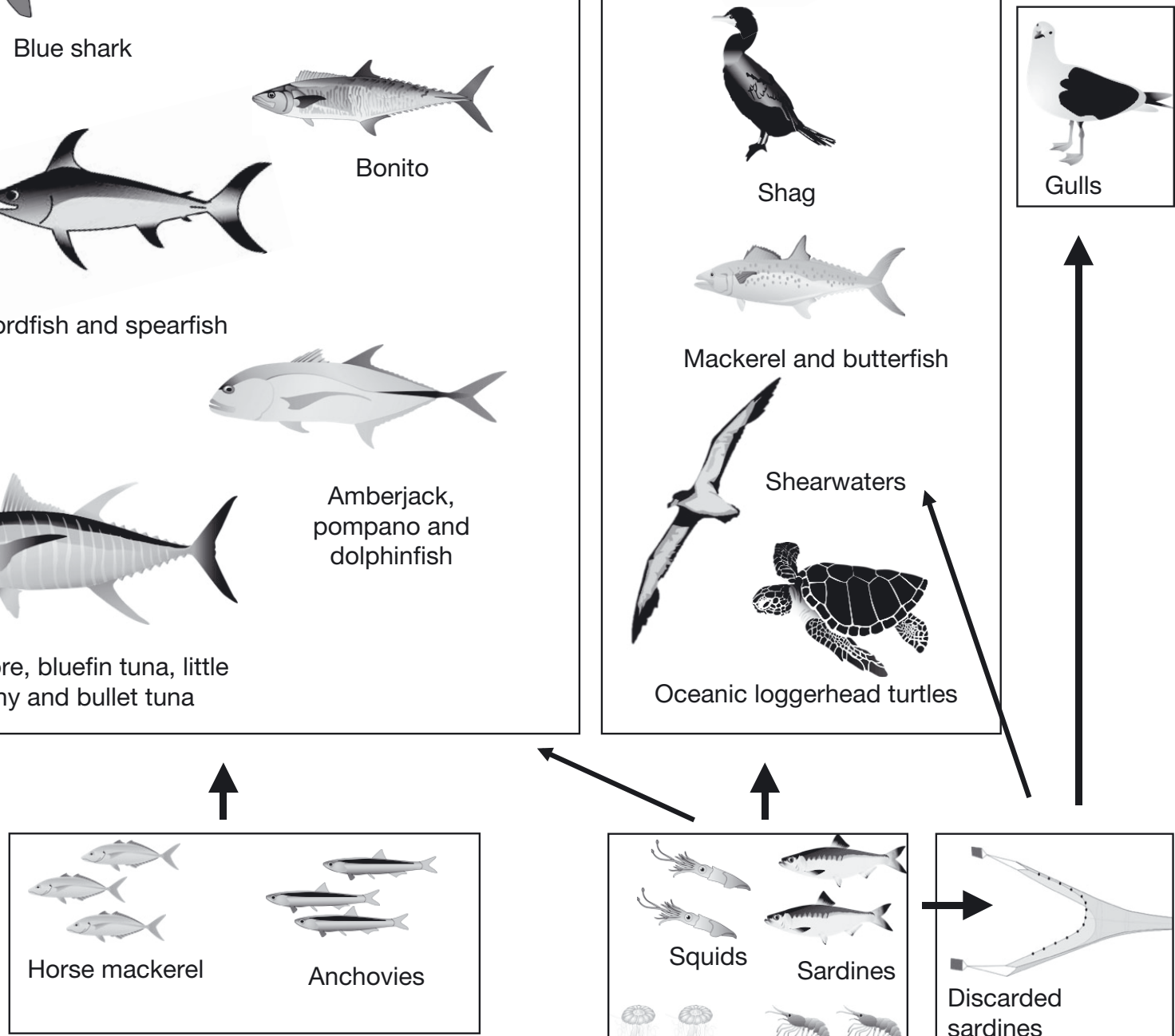

4
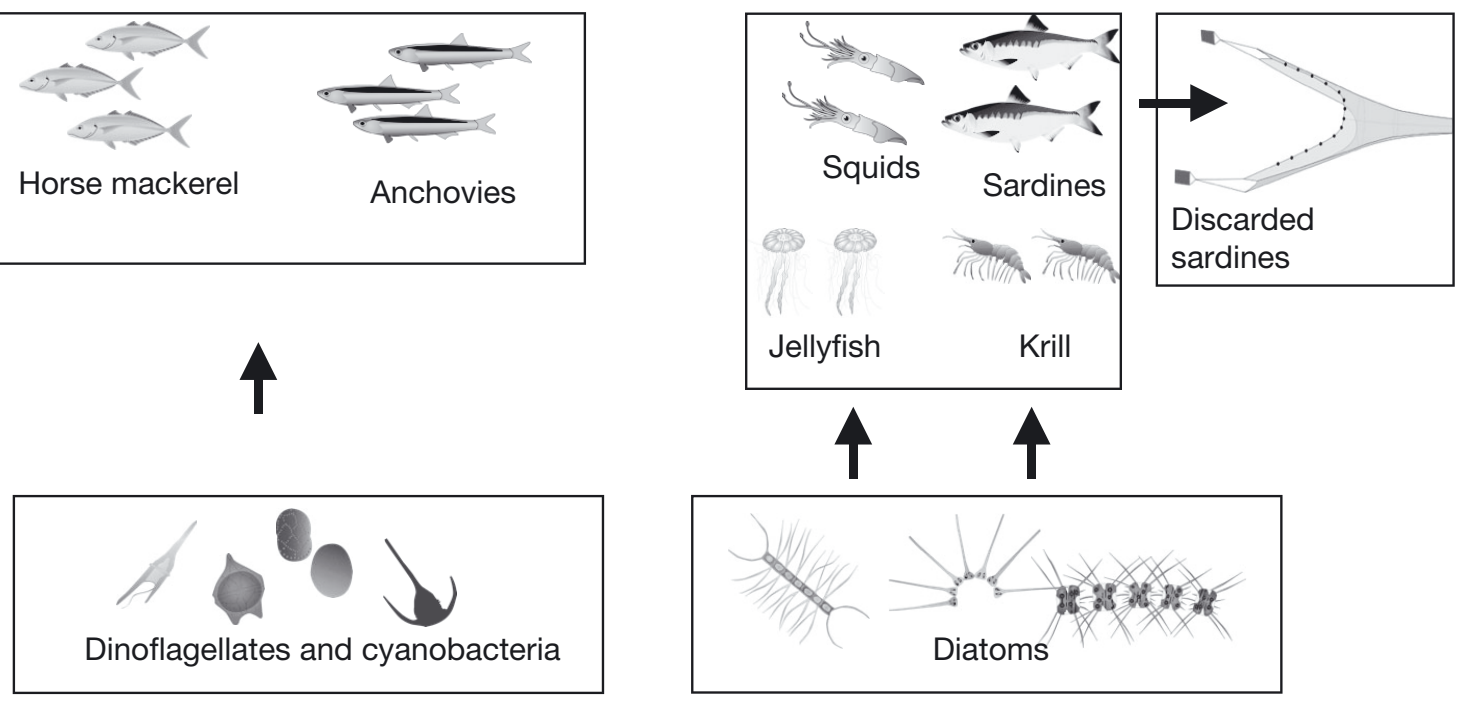

Fig. 6. Idealized representation of the pelagic food webs in the western Mediterranean Sea. Arrows show the flow of matter and energy and not direct consumption. Trophic level increases from bottom to top and intermediate trophic levels may exists, particularly between phytoplankton and small pelagic fishes. Species not drawn to scale. Swordfish and gull images from OpenClipArt.org (https://openclipart.org). All other images from IAN/UMCES symbol and image libraries (http://ian.umces.edu/imagelibrary/) 
Acknowledgements. We thank Pablo R. Camarero (IREC) for his technical support in FAMEs analysis and data processing of chromatograms. Alex Aguilar and Asunción Borrell supplied the dolphin samples.

\section{LITERATURE CITED}

Abelló P, Arcos JM, Gil de Sola L (2003) Geographical patterns of seabird attendance to a research trawler along the Iberian Mediterranean coast. Sci Mar 67 (Suppl 2): 69-75

Alfaro AC, Thomas F, Sergent L, Duxbury M (2006) Identification of trophic interactions within an estuarine food web (northern New Zealand) using fatty acid biomarkers and stable isotopes. Estuar Coast Shelf Sci 70:271-286

> Arcos JM, Oro D (2002) Significance of fisheries discards for a threatened Mediterranean seabird, the Balearic shearwater Puffinus mauretanicus. Mar Ecol Prog Ser 239:209-220

Arcos JM, Bécares J, Rodríguez B, Ruiz A (2009) Áreas importantes para la conservación de las aves marinas en España. Sociedad Española de Ornitologia (SEO/ BirdLife), Madrid

Bakun A (2006) Wasp-waist populations and marine ecosystem dynamics: navigating the 'predator pit' topographies. Prog Oceanogr 68:271-288

Bandarra NM, Batista I, Nunes ML, Empis JM (2001) Seasonal variation in the chemical composition of horsemackerel (Trachurus trachurus). Eur Food Res Technol 212:535-539

- Barlow RG, Mantoura RFC, Cummings DG, Fileman TW (1997) Pigment chemotaxonomic distributions of phytoplankton during summer in the western Mediterranean. Deep-Sea Res II 44:833-850

- Brodeur RD, Pearcy WG (1992) Effects of environmental variability on trophic interactions and food web structure in a pelagic upwelling ecosystem. Mar Ecol Prog Ser 84: 101-119

Buchheister A, Latour RJ (2010) Turnover and fractionation of carbon and nitrogen stable isotopes in tissues of a migratory coastal predator, summer flounder (Paralichthys dentatus). Can J Fish Aquat Sci 67:445-461

Cardona L, Hereu B, Torras X (2008) Juvenile bottlenecks and salinity shape grey mullet assemblages in Mediterranean estuaries. Estuar Coast Shelf Sci 77:623-632

Cardona L, Álvarez De Quevedo I, Borrell A, Aguilar A (2012) Massive consumption of gelatinous plankton by Mediterranean apex predators. PLoS ONE 7:e31329

Castriota L, Finoia MG, Campagnuolo S, Romeo T, Potoschi A, Andaloro F (2008) Diet of Tetrapturus belone (Istiophoridae) in the central Mediterranean Sea. J Mar Biol Assoc UK 88:183-187

Celik M (2008) Seasonal changes in the proximate chemical compositions and fatty acids of chub mackerel (Scomber japonicus) and horse mackerel (Trachurus trachurus) from the north eastern Mediterranean Sea. Int J Food Sci Technol 43:933-938

Chaijan M, Benjakul S, Visessanguan W, Faustman C (2006) Changes of lipids in sardine (Sardinella gibbosa) muscle during iced storage. Food Chem 99:83-91

Charles F, Lantoine F, Brugel S, Chrétiennot-Dinet MJ, Quiroga I, Rivière B (2005) Seasonal survey of the phytoplankton biomass, composition and production in a littoral NW Mediterranean site, with special emphasis on the picoplanktonic contribution. Estuar Coast Shelf Sci 65:199-212

Christensen V, Guénette S, Heymans JJ, Walters CJ, Watson R, Zeller D, Pauly D (2003) Hundred-year decline of North Atlantic predatory fishes. Fish Fish 4:1-24

Coll M, Palomera I, Tudela S, Sardà F (2006) Trophic flows, ecosystem structure and fishing impacts in the South Catalan Sea, Northwestern Mediterranean. J Mar Syst 59:63-96

Coll M, Palomera I, Tudela S, Dowd M (2008) Food-web dynamics in the South Catalan Sea ecosystem (NW Mediterranean) for 1978-2003. Ecol Modell 217:95-116

Consoli P, Romero T, Battaglia P, Castriota V, Esposito V, Andaloro F (2008) Feeding habits of the albacore tuna Thunnus alalunga (Perciformes, Scombridae) from central Mediterranean Sea. Mar Biol 155:113-120

> Costalago D, Navarro J, Álvarez-Calleja I, Palomera I (2012) Ontogenetic and seasonal changes in the feeding habits and trophic levels of two small pelagic fish species. Mar Ecol Prog Ser 460:169-181

Cury P, Bakun A, Crawford RJM, Jarre A, Quiñones RA, Shannon LJ, Verheye HM (2000) Small pelagics in upwelling systems: patterns of interaction and structural changes in 'wasp-waist' ecosystems. ICES J Mar Sci 57: $603-618$

Dalsgaard J, St. John M, Kattner G, Müller-Navarra D, Hagen W (2003) Fatty acid trophic markers in the pelagic marine environment. Adv Mar Biol 46:225-340

Darnaude AM, Salen-Picard C, Polunin NVC, HarmelinVivien ML (2004) Trophodynamic linkage between river runoff and coastal fishery yield elucidated by stable isotope data in the Gulf of Lions (NW Mediterranean). Oecologia 138:325-332

El-Sabaawi R, Dower JF, Kainz M, Mazumder A (2009) Characterizing dietary variability and trophic positions of coastal calanoid copepods: insight from stable isotopes and fatty acids. Mar Biol 156:225-237

> Falautano M, Castriota L, Finoia MG, Andaloro F (2007) Feeding ecology of little tunny Euthynnus alletteratus in the central Mediterranean Sea. J Mar Biol Assoc UK 87: 999-1005

Fernandez-Jover D, Lopez Jimenez JA, Sanchez-Jerez P, Bayle-Sempere J, Gimenez Casalduero F, Martinez Lopez FJ, Dempster T (2007) Changes in body condition and fatty acid composition of wild Mediterranean horse mackerel (Trachurus mediterraneus, Steindachner, 1868) associated to sea cage fish farms. Mar Environ Res 63: $1-18$

Frisch AJ, Ireland M, Baker R (2014) Trophic ecology of large predatory reef fishes: energy pathways, trophic level, and implications for fisheries in a changing climate. Mar Biol 161:61-73

Giannoulaki M, Iglesias M, Tugores MP, Bonanno A and others (2013) Characterizing the potential habitat of European anchovy Engraulis encrasicolus in the Mediterranean Sea, at different life stages. Fish Oceanogr 22:69-89

Gross T, Rudolf L, Levin SA, Dieckmann U (2009) Generalized models reveal stabilizing factors in food webs. Science 325:747-750

Guitart R, Guerrero X, Silvestre AM, Gutiérrez JM, Mateo R (1996) Organochlorine residues in tissues of striped dolphins affected by the 1990 Mediterranean epizootic: relationships with the fatty acid composition. Arch Environ Contam Toxicol 30:79-83

Guitart R, Silvestre AM, Guerrero X, Mateo R (1999) Com- 
parative study on the fatty acid composition of two marine vertebrates: striped dolphins and loggerhead turtles. Comp Biochem Physiol B Biochem Mol Bio 124:439-443

Hobson KA, Clark RG (1992) Assessing avian diet using stable isotopes II: factors influencing diet-tissue fractionation. Condor 94:189-197

Iglesias M, Carrera P, Muiño R (2003) Spatio-temporal patterns and morphological characterisation of multispecies pelagic fish schools in the north-western Mediterranean Sea. Aquat Living Res 16:541-548

Iverson SJ, Frost KJ, Lang SLC (2002) Fat content and fatty acid composition of forage fish and invertebrates in Prince William Sound, Alaska: factors contributing to among and within species variability. Mar Ecol Prog Ser 241:161-181

Iverson SJ, Field C, Bowen WD, Blanchard W (2004) Quantitative fatty acid signature analysis: a new method of estimating predator diets. Ecol Monogr 74:211-235

Li R, Yokota A, Sugiyama J, Watanabe M, Hiroki M, Watanabe MM (1998) Chemotaxonomy of planktonic cyanobacteria based on non-polar and 3-hydroxy fatty acid composition. Phycol Res 46:21-28

> Lloret J, Palomera I, Salat J, Solé I (2004) Impact of freshwater input and wind on landings of anchovy (Engraulis encrasicolus) and sardine (Sardina pilchardus) in shelf waters surrounding the Ebre (Ebro) River delta (northwestern Mediterranean). Fish Oceanogr 13:102-110

> Madigan DJ, Carlisle AB, Dewar H, Snodgrass OE, Litvin SY, Micheli F, Block BA (2012) Stable isotope analysis challenges wasp-waist food web assumptions in an upwelling pelagic ecosystem. Sci Rep 2:654

Marty JC, Chiaverini J, Pizay M, Avril B (2002) Seasonal and interannual dynamics of nutrients and phytoplankton pigments in the western Mediterranean Sea at the DYFAMED time-series station (1991-1999). Deep-Sea Res II 49:1965-1985

Marty JC, Garcia N, Raimbault P (2008) Phytoplankton dynamics and primary production under late summer conditions in the NW Mediterranean Sea. Deep-Sea Res I 55:1131-1149

Massutí E, Deudero S, Sánchez P, Morales-Nin B (1998) Diet and feeding of dolphin (Coryphaena hippurus) in the western Mediterranean waters. Bull Mar Sci 63:329-341

Mateo R, Beyer WN, Spann JW, Hoffman DJ (2003) Relation of fatty acid composition in lead-exposed mallards to fat mobilization, lipid peroxidation and alkaline phosphatase activity. Comp Biochem Physiol C Toxicol Pharmacol 135:451-458

Mateo R, Gil C, Badia-Vila M, Gitart R, Hernández-Matías A, Sanpera C, Ruiz X (2004) Use of fatty acids to explain variability of organochlorine concentrations in eggs and plasma of common terns (Sterna hirundo). Ecotoxicology 13:545-554

Mayzaud P, Virtue P, Albessard E (1999) Seasonal variations in the lipid and fatty acid composition of the euphausiid Meganyctiphanes norvegica from the Ligurian Sea. Mar Ecol Prog Ser 186:199-210

Mostarda E, Campo D, Castriota L, Esposito V, Scarabello MP, Andaloro F (2007) Feeding habits of the bullet tuna Auxis rochei in the southern Tyrrhenian Sea. J Mar Biol Assoc UK 87:1007-1012

Navarro J, Louzao M, Igual JM, Oro D and others (2009) Seasonal changes in the diet of a critically endangered seabird and the importance of trawling discards. Mar Biol 156:2571-2578
Nyssen F, Brey T, Dauby P, Graeve M (2005) Trophic position of Antarctic amphipods-enhanced analysis by a 2-dimensional biomarker assay. Mar Ecol Prog Ser 300: 135-145

> Olsen Y, Reinertsen H, Vadstein O, Andersen T and others (2001) Comparative analysis of food webs based on flow networks: effects of nutrient supply on structure and function of coastal plankton communities. Cont Shelf Res 21:2043-2053

> Oro D, Ruiz X, Jover L, Pedrocchi V, González-Solís J (1997) Diet and adult time budgets of Audouin's gull Larus audouinii in response to changes in commercial fisheries. Ibis 139:631-637

> Ozogul Y, Duysak O, Ozogul F, Özkütük AS, Türeli C (2008) Seasonal effects in the nutritional quality of the body structural tissue of cephalopods. Food Chem 108:847-852

Paine RT (2010) Food chain dynamics and trophic cascades in intertidal habitats. In: Terborgh J, Estes JA (eds) Trophic cascades. Island Press, Washington, DC, p 21-53

> Palomera I, Olivar MP, Salat J, Sabatés A, Coll M, García A, Morales-Nin B (2007) Small pelagic fish in the NW Mediterranean Sea: an ecological review. Prog Oceanogr 74: 377-396

Patil V, Kallqvist T, Olsen E, Vogt G, Gislerød HR (2007) Fatty acid composition of 12 microalgae for possible use in aquaculture feed. Aquacult Int 15:1-9

> Perga ME, Kainz M, Matthews B, Mazumder A (2006) Carbon pathways to zooplankton: insights from the combined use of stable isotope and fatty acid biomarkers. Freshw Biol 51:2041-2051

> Pethybridge H, Bodin N, Arsenault-Pernet EJ, Bourdeix JH and others (2014) Temporal and inter-specific variations in forage fish feeding conditions in the NW Mediterranean: lipid content and fatty acid compositional changes. Mar Ecol Prog Ser 512:39-54

> Pinnegar JK, Polunin NVC (1999) Differential fractionation of $\delta^{13} \mathrm{C}$ and $\delta^{15} \mathrm{~N}$ among fish tissues: implications for the study of trophic interactions. Funct Ecol 13:225-231

Power ME (1992) Top-down and bottom-up forces in food webs: Do plants have primacy? Ecology 73:733-746

Ramos R, González-Solís J (2012) Trace me if you can: the use of intrinsic biogeochemical markers in marine top predators. Front Ecol Environ 10:258-266

Ramos R, Ramírez R, Sanpera C, Jover L, Ruiz X (2009) Diet of yellow-legged gull (Larus michahellis) chicks along the Spanish Western Mediterranean coast: the relevance of refuse dumps. J Ornithol 150:265-272

> Robin JH, Regost C, Arzel J, Kaushik SJ (2003) Fatty acid profile of fish following a change in dietary fatty acid source: model of fatty acid composition with a dilution hypothesis. Aquaculture 225:283-293

Romeo T, Consoli P, Castriota L, Andaloro F (2009) An evaluation of resource partitioning between two billfish, Tetrapturus belone and Xiphias gladius, in the central Mediterranean Sea. J Mar Biol Assoc UK 89:849-857

> Roncarati A, Brambilla G, Meluzzi A, Iamiceli AL and others (2012) Fatty acid profile and proximate composition of fillets from Engraulis encrasicholus, Mullus barbatus, Merluccius merluccius and Sarda sarda caught in Tyrrhenian, Adriatic and Ionian seas. J Appl Ichthyology 28: 545-552

Saraux C, Fromentin JM, Bigot JL, Bourdeix JH and others (2014) Spatial structure and distribution of small pelagic fish in the Northwestern Mediterranean Sea. PLoS ONE 9:e111211 
Sargent JR (1997) Fish oils and human diet. Br J Nutr 78(Suppl 1):S5-S13

Shannon LJ, Cury PM, Jarre A (2000) Modelling effects of fishing in the Southern Benguela ecosystem. ICES J Mar Sci 57:720-722

Shealer D (2001) Foraging behavior and food of seabirds. In: Schreiber EA, Burger J (eds) Biology of marine birds. CRC Press, Boca Raton, FL, p 137-178

Shirai N, Terayama M, Takeda H (2002) Effect of season on the fatty acid composition and free amino acid content of the sardine Sardinops melanostictus. Comp Biochem Physiol B 131:387-393

Sinopoli M, Pipitone C, Campagnoulo S, Campo D, Castriota L, Mostarda E, Andaloro F (2004) Diet of young-of-theyear bluefin tuna, Thunnus thynnus (Linnaeus, 1758), in the southern Tyrrhenian (Mediterranean). Sea J Appl Ichthyol 20:310-313

Editorial responsibility: Katherine Richardson, Copenhagen, Denmark
Stowasser G, Atkinson A, McGill RAR, Phillips RA, Collins MA, Pond DW (2012) Food web dynamics in the Scotia Sea in summer: a stable isotope study. Deep-Sea Res II 59-60:208-221

Tugores MP, Giannoulaki M, Iglesias M, Bonanno A and others (2011) Habitat suitability modelling for sardine Sardina pilchardus in a highly diverse ecosystem: the Mediterranean Sea. Mar Ecol Prog Ser 443:181-205

Viso AC, Marty JC (1993) Fatty acids from 28 marine microalgae. Phytochemistry 34:1521-1533

Ware DM, Thomson RE (2005) Bottom-up ecosystem trophic dynamics determine fish production in the Northeast Pacific. Science 308:1280-1284

Zlatanos S, Laskaridis K (2007) Seasonal variation in the fatty acid composition of three Mediterranean fish-sardine (Sardina pilchardus), anchovy (Engraulis encrasicholus) and picarel (Spicara smaris). Food Chem 103:725-728

Submitted: December 1, 2014; Accepted: May 13, 2015

Proofs received from author(s): June 19, 2015 